\title{
1 Characterization of Municipal Solid Waste Collection Operations
}

2 Megan K. Jaunich ${ }^{\mathrm{a}}$, orcid.org/0000-0002-9123-3621

3 Corresponding author. Tel.: +1 919515 2331; fax: +1 919515 7908. E-mail address:

4 mkjaunic@ncsu.edu

5 James W. Levis ${ }^{\mathrm{b}}$, orcid.org/0000-0002-0485-9619

6 Joseph F. DeCarolis ${ }^{c}$, orcid.org/0000-0003-4677-4522

7 Eliana V. Gaston ${ }^{\mathrm{d}}$

8 Morton A. Barlaz

9 Shannon L. Bartelt-Hunt ${ }^{\mathrm{f}}$

10 Elizabeth G. Jones ${ }^{\mathrm{g}}$

11 Lauren Hauser $^{\mathrm{h}}$

12 Rohit Jaikumar ${ }^{\mathrm{h}}$

${ }^{a} \mathrm{PhD}$ Student, Research Assistant, Department of Civil, Construction, and Environmental

15 Engineering, North Carolina State University, Campus Box 7908, Raleigh, NC 27695

$16{ }^{\mathrm{b}} \mathrm{PhD}$, Research Assistant Professor, Department of Civil, Construction, and Environmental

17 Engineering, North Carolina State University, Campus Box 7908, Raleigh, NC 27695

$18{ }^{\mathrm{c}} \mathrm{PhD}$, Associate Professor, Department of Civil, Construction, and Environmental Engineering,

19 North Carolina State University, Campus Box 7908, Raleigh, NC 27695

$20 \quad{ }^{\mathrm{d}}$ B.S., North Carolina State University

$21{ }^{\mathrm{e}} \mathrm{PhD}$, Professor and Head, Department of Civil, Construction, and Environmental Engineering,

22 North Carolina State University, Campus Box 7908, Raleigh, NC 27695

$23{ }^{\mathrm{f}} \mathrm{PhD}$, Associate Professor, Department of Civil Engineering, University of Nebraska-Lincoln,

24 Omaha, NE 68182-0178

$25{ }^{\mathrm{g}} \mathrm{PhD}$, Associate Professor, Department of Civil Engineering, University of Nebraska-Lincoln, 26 Omaha, NE 68182-0178

$27{ }^{\mathrm{h}}$ MS Student, Department of Civil Engineering, University of Nebraska-Lincoln, Omaha, NE $28 \quad 68182-0178$

\section{Abstract}

33 perform integrated assessments of solid waste management alternatives using a life-cycle

34 approach; however, models are only as good as their parameterization. This study presents

35 operational waste collection data that can be used in life-cycle models for areas with similar

36 collection systems, and provides illustrative results from a collection process model using 
37 operational data. Fuel use and times associated with various aspects of waste collection were

38 obtained for vehicles collecting mixed residential (residual) waste, recyclables, and yard waste

39 from single-family residences in selected municipalities. The total average fuel economy for

40 similarly-sized diesel collection vehicles was 0.6-1.4 km/L (1.4-3.3 miles per gallon (mpg)) for

41 residual waste and 0.8-1 km/L (1.9-2.4 mpg) for recyclables. For residual waste and recyclables

42 collection stops, the average time to collect at each residence using automated collection was 11-

$43 \quad 12$ seconds and 13-17 seconds, respectively. The average time between stops was 11-12 seconds

44 and 10-13 for residuals and recyclables, respectively. A single yard waste route was observed,

45 and all collection times were longer than those measured for either recycling or residual waste.

46 Unload or tip times were obtained or measured at a landfill, transfer station, and material

47 recovery facility (MRF). Average time to unload was 7-9 minutes at a MRF, 14-22 minutes at a

48 landfill, and 11 minutes at a transfer station. Commercial and multi-family collection vehicles

49 tend to have longer stops and spend more time between stops than single-family collection, and a

50 larger portion of fuel is used while driving relative to single-family collection. Roll-off vehicles,

51 which collect more waste per stop, spend longer at each stop and drive longer distances between

52 stops than front-loader vehicles. Diesel roll-offs averaged $2.4 \mathrm{~km} / \mathrm{L}(5.7 \mathrm{mpg})$ and front-loaders

53 averaged $1.4 \mathrm{~km} / \mathrm{L}(3.3 \mathrm{mpg})$.

\section{$54 \quad$ Keywords}

55 collection; municipal solid waste; collection time; collection distance; collection fuel efficiency

\section{Introduction}

57 Waste collection is an integral component of solid waste management (SWM) systems

58 that contributes to both the costs and environmental emissions associated with managing solid

59 waste. Although collection costs vary depending on population, population density, location, 
60 labor costs, and many other factors, waste collection has been reported to contribute over $40 \%$ of

61 the total cost of municipal solid waste (MSW) management (Chalkias and Lasaridi 2009).

62 Emissions from collection vehicles vary based on factors such as truck type, fuel type,

63 efficiency, and route characteristics, but collection has consistently been found to be the most

64 fuel-intensive process in SWM systems (NREL 1995). Therefore, a systematic characterization

65 of the collection process is critical for developing and evaluating MSW management programs

66 that cost-effectively minimize environmental emissions and energy use.

67 Limited collection process data have been previously reported. Agar et al. (2007)

68 presented collection operation times and fuel use obtained by examining global positioning

69 system (GPS) records of refuse collection vehicles, but this did not include stop duration or time

70 between stops, which are necessary to mechanistically estimate both truck and fuel requirements.

71 Farzaneh et al. (2009) presented data on truck and fuel requirements, as well as durations and

72 distances for all collection activities (e.g., transit to landfill, unloading) for three truck-days of

73 collection. Measurements have been reported on refuse collection vehicles to better characterize

74 emissions (Farzaneh et al. 2009) and engine performance (Ivani 2007) during different operation,

75 including urban driving, highway driving, refuse collection, and disposal activities. More

76 recently, emissions and fuel use rates were measured for diesel and natural gas automated side

77 loaders (Sandhu et al. 2016), diesel front loaders (Sandhu et al. 2014), and diesel roll-off

78 collection vehicles (Sandhu et al. 2015). Heavy-duty diesel vehicles (HDDVs), a class that

79 includes collection vehicles, have an estimated fuel efficiency of 2.8 to $3.2 \mathrm{~km} / \mathrm{L}$ (6.6 to 7.5

$80 \mathrm{mpg}$ ) (US EPA 2006). Since refuse trucks stop and start much more frequently than other

81 HDDVs, they are expected to have lower fuel efficiency. A 2008 model year Autocar refuse

82 collection truck with a Cummins diesel interact system model L (ISL) engine, for example, was 
83 reported to average $1.15 \mathrm{~km} / \mathrm{L}$ (2.94 mpg) (WIH Resource Group 2010). Values published in the

84 literature for refuse vehicles vary significantly due to many factors including differences in

85 collection vehicle fleet, housing density, and route characteristics. Additionally, fuel efficiencies

86 per distance travelled do not consistently account for the fuel used during loading and unloading

87 of waste, which can also vary significantly.

88 The objectives of this study were to 1) develop a set of empirical collection data to

89 characterize MSW collection, 2) develop a set of default input parameters for use in mechanistic

90 life-cycle collection models, and 3) illustrate how model parameters can be employed in a

91 specific collection model.

92 The next section describes the acquisition and analysis of waste collection data. This is

93 followed by presentation and discussion of measured collection data as well as data obtained

94 from collection vehicle fleet operators and waste facility operators. Finally, a default data set for

95 single-family residential collection is described. This data set is employed in the collection

96 process model (Jaunich et al., forthcoming 2016) of the Solid Waste Optimization Life-cycle

97 Framework (SWOLF) (Levis et al. 2013) and illustrative results are discussed.

$98 \quad 2 \quad$ Methods

99 Waste collection data were assembled for several cities in the U.S. (Table 1). A number

100 of route parameters for single-family collection of recyclables, yard waste, and residual waste

101 were directly measured for City A. In the U.S., recyclables collection typically includes

102 aluminum and steel cans, glass containers, paper, cardboard, and several types of plastic

103 containers. In addition, data were provided by several municipalities and private collection

104 companies (Cities B - E). Collection activity data obtained during a recent collection vehicle

105 emissions study for City F were also incorporated (Sandhu et al. 2014, 2015). 


\section{Table 1. Characteristics of Organizations Providing Waste Collection Data}

\begin{tabular}{|c|c|c|c|c|}
\hline $\begin{array}{l}\text { Location or } \\
\text { organization } \\
\text { providing } \\
\text { data }^{a}\end{array}$ & $\begin{array}{l}\text { Population } \\
\text { density } \\
\left(\mathrm{pp} / \mathrm{km}^{2}\right)\end{array}$ & $\begin{array}{l}\% \text { Multi- } \\
\text { family } \\
\text { units } \\
\text { (MF) }\end{array}$ & $\begin{array}{l}\text { People/ } \\
\text { house- } \\
\text { hold }\end{array}$ & Data Provided or Measured ${ }^{c, d}$ \\
\hline City A & 1080 & $27 \%$ & 2.7 & $\begin{array}{l}\text { Obtained monthly fuel consumption and associated } \\
\text { tonnage; observed four collection routes (one yard waste, } \\
\text { one recyclables, two residual) and recorded distances, } \\
\text { times, tonnages [calendar year (CY) 2012] }\end{array}$ \\
\hline City B & 1180 & $32 \%$ & 2.8 & $\begin{array}{l}\text { Obtained GPS tracking data for } 2 \text { diesel and } 2 \text { CNG trucks } \\
\text { over } 4 \text { collection days, for both residual and recyclables } \\
\text { collection (route distances, times, tonnages) [CY 2012] }\end{array}$ \\
\hline City C & 4250 & $62 \%$ & 2.2 & $\begin{array}{l}\text { Obtained monthly fuel use and tonnage for } 68-77 \text { residual } \\
\text { waste vehicle routes and } 45-62 \text { recyclables collection } \\
\text { routes [CY 2011] }\end{array}$ \\
\hline City D & 1160 & $32 \%$ & 2.8 & $\begin{array}{l}\text { Obtained engine control module (ECM) records for residual } \\
\text { and recyclables collection vehicles (e.g. fuel efficiency, total } \\
\text { distance travelled) [CY 2010] }\end{array}$ \\
\hline City $\mathrm{E}$ & 1110 & $39 \%$ & 2.4 & $\begin{array}{l}\text { Observed unload (tip) times (one day) at a material } \\
\text { recovery facility (MRF); obtained tip times for City E tips for } \\
\text { several days of operation [CY 2012] }\end{array}$ \\
\hline City $E$ & 1110 & $39 \%$ & 2.4 & $\begin{array}{l}\text { Obtained tip times for landfill and transfer station for several } \\
\text { days of operation [CY 2012] }\end{array}$ \\
\hline City F & 1110 & $39 \%$ & 2.4 & $\begin{array}{l}\text { Collection vehicle emissions study provided fuel use, } \\
\text { mileage, tons per trip, tons per stop and collection activity } \\
\text { times and distances for single- and multi-family residential } \\
\text { and commercial collection [CY 2013] }\end{array}$ \\
\hline
\end{tabular}

$107{ }^{a}$ All cities are located in the U.S.

$108{ }^{\mathrm{b}}$ Percent of housing units which are multi-family (U.S. Census City Data, 2014)

$109{ }^{c}$ Collection activity and route data were for single-family residential collection except where noted

$110 \quad{ }^{\mathrm{d}}$ All collection vehicles were diesel except where noted

113 the fuel efficiency $(\mathrm{L} / \mathrm{kg})$, fuel use per metric ton $(\mathrm{Mg})$ waste, and effective in-truck density (i.e.,

$114 \mathrm{Mg} / \mathrm{m}^{3}$ ). Because of the variety of data sources and formats, city-specific details are described

115 below.

\section{City A}

117 Collection vehicles performing single-family residential collection of recyclables, yard

118 waste, and residual waste were followed in a trailing passenger vehicle to record transit times,

119 distances, time at each collection location, and unload (tip) time at the disposal facility using a

120 handheld GPS. Trip logs provided fuel quantity and tonnage disposed. Recyclables and residual 
121 waste routes used automated side-loaders (ASL) while the yard waste route was serviced by a

122 rear-loader $(\mathrm{RL})$.

\section{City B}

124 GPS logs were supplied for eight residual truck-days for diesel vehicles collecting

125 residual waste, eight collection truck-days for compressed natural gas $(\mathrm{CNG})$ vehicles also

126 collecting residual waste, and seventeen collection truck-days for diesel vehicles collecting

127 recyclables $\left(28 \mathrm{yd}^{3}\left(21 \mathrm{~m}^{3}\right)\right)$. All vehicles were ASLs. Logs included truck number, date, speed,

128 distance traveled, latitude and longitude, and address. Route times and distances were

129 determined from the GPS logs and arm actuation.

130 City C

131 City $\mathrm{C}$ provided monthly records of tonnage unloaded at the disposal facility for a fleet of

13268 to 77 vehicles that were used for both residual waste collection and recyclables collection.

133 Because of the overlap in vehicle use, the calculated distance travelled per quantity of fuel

134 consumed is an aggregate of residual waste and recycling collection. Average waste tonnage per

135 trip was provided for 880 vehicle-days for residual waste collection and 641 vehicle-days for

136 recyclables collection. Effective in-truck waste density was estimated for residual waste and

137 recyclables using the nominal truck volume of $13.4 \mathrm{~m}^{3}\left(16 \mathrm{yd}^{3}\right)$.

\section{City D}

139 City D furnished fuel and cost data from its waste management provider. The city

140 provided records from the engine control module (ECM) for 17 diesel collection vehicles, which

141 were all $27 \mathrm{yd}^{3}\left(21 \mathrm{~m}^{3}\right)$ automated side-loaders. Data represented over 100,000 $\mathrm{hr}$ of collection

142 vehicle operation. The ECMs recorded the volume of fuel consumed during driving $(>2.8 \mathrm{~km} / \mathrm{hr}$,

$1431.2 \mathrm{mph})$ and idling $(<2.8 \mathrm{~km} / \mathrm{hr})$. The fuel use data were provided for each vehicle over the 
144 entire time span of operation, and the average idle fuel economy ( $\mathrm{L} / \mathrm{hr}$ of idling) and the overall

145 average fuel economy $(\mathrm{km} / \mathrm{L})$ were calculated.

146 City E

147 Operators from a landfill, transfer station, and material recovery facility each supplied 148 unload (tip) times for collection vehicles. Additionally, tip times were observed and recorded for 149 one day of operation at a MRF. Tip time was measured from facility check-in to check out.

150 City $\mathbf{F}$

Sandhu et al. (2014, 2015, 2016) performed a collection vehicle emissions study in

152 Raleigh, NC. Engine control units and GPS devices tracked fuel use, distances, and times on 153 refuse collection vehicles, in addition to using a portable emissions measurement system to track 154 emissions, which was the primary study objective. Six diesel and three CNG truck-days were 155 monitored for both ASL and front-loader (FL) vehicles, as well as six truck-days of diesel roll156 off (RO) vehicles. Times at each stop, at the disposal facility, and other route times and distances 157 were presented, as well as the fraction of fuel and time spent driving and idling.

\section{$158 \quad 3 \quad$ Results}

159 Single-family residential collection data are presented first (Section 3.1), followed by multi160 family and commercial collection data (Section 3.2). Based on these results, a default set of 161 collection inputs is presented, showing proposed low, middle, and high values for single-family 162 collection input parameters (Section 3.3). Lastly, the SWOLF collection process model (Jaunich 163 et al. 2015,) is summarized and used to predict collection fuel use, cost, and number of trucks for 164 "better", "medium", and "worse"-case scenarios based on the range of default input values 165 (Section 3.4).

\section{$166 \quad 3.1 \quad$ Single-family Residential Collection Data}


168 brought to the curb of single-family houses, or in some cases duplex-style homes. Collection

169 vehicles then empty the waste containers into the truck manually or with an automated arm. This

170 section describes the quantity of waste collected, the density of the waste (in terms of waste per

171 available truck volume), vehicle fuel use, and collection activity times and distances.

\section{$172 \quad$ 3.1.1 Mass of Waste Collected}

173 Data on the quantity of waste collected per stop were collected from Cities A and B and

174 are summarized in Table 2. City A collected less residual waste per stop than City B (16.2 vs.

$17522.6 \mathrm{~kg}$ ), although both cities performed weekly collection. The mass of residual waste collected

176 per stop will vary based on the collection services offered, the frequency of collection, the waste

177 composition and generation rate, the average household size, and the number of households per

178 stop. City A offered weekly collection of residual and yard waste, and bi-weekly recyclables

179 collection. City B provided weekly residual and recycling collection, but offers only limited yard

180 waste collection (twice annually, or upon request). Cities A and B are in the mid-Atlantic and

181 Southwest, respectively. As such, considerably less yard waste is likely generated in City B.

182

183

184

185

186

187

188

189

190

191

192

193

194

195

196

197 


\begin{tabular}{|c|c|c|c|c|c|c|c|c|c|c|c|c|}
\hline $\begin{array}{r}\text { City }^{\mathrm{a}} \\
\text { Service }\end{array}$ & $\begin{array}{c}\mathrm{A}, \\
\mathrm{RW}^{\mathrm{b}}\end{array}$ & $\begin{array}{c}\text { A, } \\
\operatorname{Rec}^{c}\end{array}$ & $\begin{array}{c}A^{d}, \\
\operatorname{Rec}^{c}\end{array}$ & $\begin{array}{c}\mathrm{A}, \\
\mathrm{YW}^{\mathrm{e}}\end{array}$ & $\begin{array}{c}A^{f}, \\
R / Y^{f}\end{array}$ & $\begin{array}{c}\mathrm{B}, \\
\mathrm{RW}^{\mathrm{b}}\end{array}$ & $\begin{array}{c}\mathrm{B}, \\
\mathrm{Rec}^{\mathrm{c}}\end{array}$ & $\begin{array}{c}\mathrm{C} \\
\mathrm{RW}^{\mathrm{b}}\end{array}$ & $\begin{array}{c}\mathrm{C}, \\
\mathrm{Rec}^{\mathrm{c}}\end{array}$ & $\begin{array}{c}\mathrm{D}, \\
\mathrm{RW}^{\mathrm{b}}\end{array}$ & $\begin{array}{c}\mathrm{F}, \\
\mathrm{RW}^{\mathrm{b}}\end{array}$ & $\begin{array}{c}\mathrm{F}^{\mathrm{g}} \\
\mathrm{RW}^{\mathrm{b}}\end{array}$ \\
\hline $\begin{array}{l}\text { Effective } \\
\text { density } \\
\left(\mathrm{kg} / \mathrm{m}^{3}\right)\end{array}$ & $\begin{array}{l}464 \\
{[2 T]^{h}}\end{array}$ & $\begin{array}{l}160 \\
{[2 T]^{h}}\end{array}$ & - & $\begin{array}{c}94 \\
{[2 T]^{h}}\end{array}$ & - & $\begin{array}{c}353 \\
{[32 T]^{h}}\end{array}$ & $\begin{array}{c}195 \\
{[120 T]^{h}}\end{array}$ & $\begin{array}{c}344 \\
{[880 \mathrm{D}]^{\mathrm{j}}}\end{array}$ & $\begin{array}{c}275 \\
{[641 \mathrm{D}]^{\mathrm{j}}}\end{array}$ & - & - & - \\
\hline $\begin{array}{l}\text { Waste } \\
\text { per stop } \\
\text { (kg/stop) }\end{array}$ & $\begin{array}{c}16.2 \\
{[1269 S]^{i}}\end{array}$ & $\begin{array}{c}12.0 \\
{[590 S]^{i}}\end{array}$ & - & $\begin{array}{c}15.5 \\
{[270 S]^{i}}\end{array}$ & - & $\begin{array}{c}22.6 \\
{[15,400 S]^{\mathrm{i}}}\end{array}$ & - & - & - & - & - & - \\
\hline $\begin{array}{l}\text { Fuel use } \\
\text { (L/Mg) }\end{array}$ & $\begin{array}{l}11.0 \\
{[2 D]^{j}}\end{array}$ & $\begin{array}{l}18.2 \\
{[1 D]^{j}}\end{array}$ & $\begin{array}{l}20.2 \\
{[1 Y]^{k}}\end{array}$ & - & $\begin{array}{c}9.8 \\
{[1 Y]^{k}}\end{array}$ & $\begin{array}{c}9.2 \\
{[20 \mathrm{D}]^{\mathrm{j}}}\end{array}$ & $\begin{array}{c}22.3 \\
{[60 D]^{j}}\end{array}$ & - & - & - & - & - \\
\hline $\begin{array}{l}\text { Avg. eff. } \\
(\mathrm{km} / \mathrm{L})\end{array}$ & $\begin{array}{c}0.7 \\
{[2 \mathrm{D}]^{\mathrm{j}}}\end{array}$ & $\begin{array}{c}1.0 \\
{[1 \mathrm{D}]^{\mathrm{j}}}\end{array}$ & - & - & - & $\begin{array}{c}0.9 \\
{[20 \mathrm{D}]^{\mathrm{j}}}\end{array}$ & $\begin{array}{c}0.8 \\
{[20 D]^{j}}\end{array}$ & $\begin{array}{c}1.0 \\
{[1 \mathrm{M}]^{\prime}}\end{array}$ & $\begin{array}{c}1.0 \\
{[1 \mathrm{M}]^{\prime}}\end{array}$ & $\begin{array}{c}1.1 \\
{\left[10^{5} \mathrm{H}\right]^{\mathrm{m}}}\end{array}$ & $\begin{array}{c}1.3 \\
{[6 D]^{j}}\end{array}$ & $\begin{array}{c}0.6 \\
{[3 D]^{\mathrm{j}}}\end{array}$ \\
\hline $\begin{array}{l}\text { Idle eff. } \\
(\mathrm{L} / \mathrm{hr})\end{array}$ & - & - & - & - & - & - & - & - & - & $\begin{array}{c}7.8 \\
{\left[10^{5} \mathrm{H}\right]^{\mathrm{m}}}\end{array}$ & - & - \\
\hline $\begin{array}{l}{ }^{\mathrm{a}} \text { Cities de } \\
{ }^{\mathrm{b}} \mathrm{RW}-\mathrm{R} \\
{ }^{\mathrm{c}} \mathrm{RW} \\
{ }^{\mathrm{C}} \mathrm{Rec}-\mathrm{R} \\
{ }^{\mathrm{d}} \text { Data are } \\
\text { period } \\
{ }^{\mathrm{e}} \mathrm{YW}-\mathrm{Ya} \\
{ }^{\mathrm{f}} \mathrm{R} / \mathrm{Y}-\mathrm{Da} \\
\text { residual }\end{array}$ & $\begin{array}{l}\text { ignated b } \\
\text { sidual wa } \\
\text { cyclables } \\
\text { rom the } \\
\text { d waste } \\
\text { a are fron } \\
\text { laste and }\end{array}$ & $\begin{array}{l}\text { A throug } \\
\text { collecti } \\
\text { bllection } \\
\text { blic work } \\
\text { lection } \\
\text { he comb } \\
\text { ard wast }\end{array}$ & $\begin{array}{l}\text { depar } \\
\text { hed col }\end{array}$ & etion da & $\begin{array}{l}1-y r \\
\text { for }\end{array}$ & \multicolumn{7}{|c|}{$\begin{array}{l}{ }^{g} \mathrm{RW} \text { collection routes in city F serviced by CNG vehicles } \\
{ }^{\mathrm{h}} \mathrm{T}-\text { number of collection vehicle trips } \\
{ }^{\mathrm{i}} \mathrm{S}-\text { number of collection vehicle stops } \\
{ }^{\mathrm{j}} \mathrm{D}-\text { number of collection vehicle-days } \\
{ }^{\mathrm{k}} \mathrm{Y}-\text { number of years of collection vehicle fleet operations } \\
{ }^{\mathrm{I}} \mathrm{M} \text { - number of months of collection vehicle fleet operations } \\
{ }^{\mathrm{m}} \mathrm{H} \text { - number of hours of collection vehicle fleet operations }\end{array}$} \\
\hline
\end{tabular}
residual waste and yard waste

$\mathrm{H}$ - number of hours of collection vehicle fleet operations

Based on the average household size of each city (2.7 and 2.8 persons/household,

respectively), the collected residual waste per stop corresponds to $0.79 \mathrm{~kg} /$ person-day for City A

204 would result in average residual waste generation of $1.31 \mathrm{~kg} /$ person-day. Because the EPA

205 definition of MSW includes waste not collected in a residential collection system (e.g.,

206 commercial and institutional waste), it is expected that residual collection mass observed would

207 be lower than EPA averages.

\section{$208 \quad 3.1 .2$ Waste Density}

Jaunich et al. (forthcoming 2016) showed that the mass collected at each stop on a

210 collection route significantly affects the cost and fuel use because it influences the length of time

211 required to fill the truck and therefore the total number of trips to the disposal facility that a truck

212 can make in a given day. Estimating the mass collected during each route requires an estimate of 
213 the mass required to fill a specified truck volume. An effective in-truck density was calculated by

214 dividing the mass of waste in the truck when it unloads by the volume of the collection vehicle.

215 Table 2 shows the effective in-truck density for recyclables and residual waste for Cities A, B,

216 and C, and yard waste for City A. This effective density is less than the maximum potential

217 density in the truck because it is based on the total mass of waste collected which is often lower

218 than the maximum capacity of the truck by mass. In each city, residual waste had a higher

219 effective density than recyclables or yard waste. The most likely explanation for this is that

220 residual waste would be expected to contain more wet dense material such as food waste, as

221 opposed to the relatively dry recyclables stream and the bulky yard waste stream.

\section{$222 \quad 3.1 .3 \quad$ Fuel Use}

223 Available data on collection vehicle fuel consumption from Cities A and B are

224 summarized in Table 2. For both cities, fuel consumption per metric ton of waste collected was

225 higher for recyclables than residual collection. This is expected because the household

226 generation rate of recyclables is lower (i.e., less waste is collected per stop), and the effective

227 density of recyclables is lower than residual waste (i.e., a full truck has less mass in it). For City

228 A, residual waste made up just over two thirds of total mass, with recyclables and yard waste

229 making up $16 \%$ and $15 \%$, respectively. Observed effective waste densities for recyclables ranged

230 from 160 to $195 \mathrm{~kg} / \mathrm{m}^{3}$, while residual waste was 353 to $464 \mathrm{~kg} / \mathrm{m}^{3}$ (Table 2). Fuel consumption

231 per metric ton of residual waste was $17 \%$ higher for City A relative to City B. This is likely

232 explained by the lower fuel efficiency observed for City A $(0.7 \mathrm{~km} / \mathrm{L})$ compared with city B $(0.9$

$233 \mathrm{~km} / \mathrm{L}$ ). Differences in network distances (e.g., route to disposal facility) would also contribute.

\section{$234 \quad 3.1 .4$ Fuel Economy}


Figure 1 shows the range of average fuel economies compared with results from two

236 reports of fuel economy during collection vehicle operation. For observed routes where data

237 were available, overall average fuel economy of diesel vehicles ranged from 0.7 to $1.4 \mathrm{~km} / \mathrm{L}(1.7$

238 to $3.3 \mathrm{mpg}$ ) for residual or recycling routes. The fuel efficiency in Figure 1 includes all modes of

239 operation for each route (i.e., average fuel efficiency is the total distance traveled by a vehicle,

240 divided by its total fuel consumption during all operations). There was not a consistent trend in

241 fuel economy between residual or recycling routes. The values in Figure 1 are within the range

242 for average collection vehicle fuel efficiency in two recent studies: $0.9 \pm 0.44 \mathrm{~km} / \mathrm{L}(2.1 \pm 1.0$

$243 \mathrm{mpg}$ ) in the city of Hamilton, Ontario, Canada (Agar et al. 2007) and 1.5 to $1.7 \mathrm{~km} / \mathrm{L}$ (3.5 to 4

$244 \mathrm{mpg}$ ) in the City of El Paso, Texas (Farzaneh et al., 2009). The first study had sufficient data to

245 include error bars (1 standard deviation), while the second was based on three collection-days.

246 Data acquired from City D included the distinction between fuel and time spent while

247 idling and driving. Thus, it was possible to compare fuel consumption during the different

248 operating modes for City D with those measured by Farzaneh and Agar, whose results included

249 efficiency while idling as well as idling with trash lifting (not shown in Figure 1). Fuel use

250 during idling for City D trucks was $7.8 \mathrm{~L} / \mathrm{hr}(2.1 \mathrm{gal} / \mathrm{hr})$, which included time spent picking up

251 and compacting waste. This was between Agar et al. (2009), which reported an average of 3.1

$252 \mathrm{~L} / \mathrm{hr}(0.82 \mathrm{gal} / \mathrm{hr})$ during all time spent idling, and Farzaneh et al. (2009) which reported 3.9 L/hr

253 (1.03 gal/hr) while idling with no arm use and 10.2 L/hr (2.7 gal/hr) during idling while using the

254 vehicle arm to lift and tip cans.

255 City D provided ECM records of over 100,000 hours of operation. Figure 2 shows that

256 while $42 \%$ of collection time was spent idling, only $22 \%$ of total fuel use occurred during idling

257 for City D vehicles. Collection activity and fuel consumption data for City F illustrated a similar 
258 trend, where a larger fraction of time than fuel was spent idling, for both diesel and CNG

259 vehicles (Figure 2). These values have a similar trend to that reported by Agar et al. (2007),

260 where it was estimated that $52 \%$ of collection time was spent idling, but idling only accounted

261 for $16 \%$ of fuel use. Similar data for multi-family and commercial collection activities are

262 discussed in Section 3.3.

263 City F collection trucks spent a larger portion of the collection day idling than City D

264 trucks, with CNG trucks in City F idling for two thirds of the collection day. Sources of

265 variability include whether or not the truck was left idling during crew breaks, traffic conditions,

266 distance between stops, and network distances (e.g., distances to garage and disposal site).

267 3.1.5 Collection Activity Times and Distances

268 Time, distance, and speed metrics for collection and transit activities are presented in

269 Table 3. Transit distances are based on the location of the garage, route, and disposal facility and

270 the typical routes used.

271 
272 Table 3. Collection transit distances, times, and speeds

\begin{tabular}{|c|c|c|c|c|c|c|c|}
\hline & $\begin{array}{l}\text { City A } \\
\text { RW }\end{array}$ & $\begin{array}{l}\text { City A } \\
\text { Rec }\end{array}$ & $\begin{array}{l}\text { City A } \\
\text { YW }\end{array}$ & $\begin{array}{l}\text { City B } \\
\text { RW }\end{array}$ & $\begin{array}{l}\text { City B } \\
\text { RW }^{\mathrm{a}}\end{array}$ & $\begin{array}{c}\text { City B } \\
\text { Rec }\end{array}$ & $\begin{array}{l}\text { City F } \\
\text { RW }^{\mathrm{b}}\end{array}$ \\
\hline $\begin{array}{l}\text { Observations }\left(\text { trips }^{c}\right) \\
\text { Travel times (minutes }\end{array}$ & 3 & 2 & 1 & 16 & 23 & 16 & 10 \\
\hline garage to route & 7 & 6 & 6 & $-{ }^{d}$ & - & 12 & 26.1 \\
\hline route to facility & 25 & 18 & 23 & 18 & 23 & 26 & 16.9 \\
\hline facility to garage & - & 19 & - & 25 & 15 & 23 & 11.7 \\
\hline \multicolumn{8}{|l|}{ Travel distances (km) } \\
\hline garage to route & 6.0 & 3.5 & 6.4 & - & - & 9.5 & 19.3 \\
\hline route to facility & 20.0 & 34.6 & 28.0 & 15.9 & 15.0 & 20.9 & 20.0 \\
\hline facility to garage & - & 40.7 & - & 19.0 & 12.9 & 22.5 & 12.9 \\
\hline \multicolumn{8}{|c|}{ Travel speeds (km/hour) } \\
\hline garage to route & 51.5 & 35.4 & 64.4 & - & - & 47.5 & 44.3 \\
\hline route to facility & 48.3 & 111.0 & 72.4 & 54.7 & 38.6 & 48.2 & 50.8 \\
\hline facility to garage & - & 128.7 & - & 46.7 & 53.1 & 58.7 & 54.2 \\
\hline
\end{tabular}

273

${ }^{a}$ CNG collection vehicles

${ }^{\mathrm{b}}$ Includes six diesel and three CNG collection vehicles

${ }^{\mathrm{c}}$ Trips are defined as filling a truck, unloading at a facility, and returning to the collection route

${ }^{d}$ Distance/time data was unavailable for some routes

Two important parameters for characterizing refuse collection are the average stop

duration at a service location and the transit time between collection stops (Appendix Table A2).

Data from Cities A and B illustrate that the distribution of stop durations and transit times are both positively skewed (Figure 3) (i.e., there is more variability in the upper $50 \%$ of the data).

This is becasue while most stops were approximately 10 seconds, the range for stop duration was large as some drivers or collectors provided additional service at certain houses (e.g., bringing trash bin from the house to the curb and back for households with elderly or disabled customers).

Similarly, the majority of transit times were on the order of 10 seconds, but the range was large because inter-street and inter-neighborhood times were included. The stop times for yard waste 288 curbside (e.g., bagged leaves, loose branches, bins of yard waste). Appendix Table T-A1 
presents the values for each metric described here, as well as the mean and mode of each 290 distribution.

291 When a truck enters a disposal, treatment, or transfer facility carrying residual waste or 292 recyclables, it is typically weighed and the time of arrival is recorded. The term "tip time" is 293 used to denote the duration between arrival and departure from the facility, which may include 294 the vehicle driving to the unload location, waiting in queue, unloading the residual waste or 295 recyclables, driving to the facility exit, getting weighed, and then departing. Tip times for 296 observed collection routes were recorded, but there were relatively few instances for each city. 297 As a result, only tip times from City E, which had a large number of tips, are shown in Figure 4. 298 The average time required to unload at a landfill for observed collection routes in Cities A 299 (Appendix T-A1), B (Appendix T-A1), and E ranged from 12 to 22 minutes. Longer tip times at 300 landfills relative to MRFs and transfer stations could be expected as there is generally a longer 301 distance between the weigh station and the disposal area and more truck maneuvering is typically 302 required at landfills. Average tip times by City B (Appendix T-A1) and City E at transfer stations 303 ranged from 11-12 minutes, and tips at the City E area MRF ranged from 7-9 minutes. In 304 addition to variation in tip times between different types of facilities, facility-specific factors also 305 play a role in the time needed to unload at facilities of the same type. In general, the distributions illustrated in Figure 4 are positively skewed, with a few 307 instances of longer tip times influencing the mean. Since life-cycle collection process models are 308 not intended for detailed route planning, average tip times are useful. However, it is preferable to 309 have a large dataset for a given disposal, treatment or transfer facility so that outliers during a 310 particular hour or day do not have a disproportionate impact on the mean. Knowing the 311 distribution of input parameters is also valuable for sensitivity and uncertainty analysis. 


\subsection{Multi-family Residential and Commercial Collection Data}

Fuel consumption and collection activity data for commercial and multi-family sector

314 collection are presented in this section. These data were derived from Sandhu et al. (2014, 2015),

315 who made measurements on front-end loading and roll-off vehicles serving the multi-family and

316 commercial sectors. Six diesel front-loaders collecting a mix of multi-family residential MSW,

317 commercial waste, and cardboard (recyclables) were observed in the study, along with three

318 CNG front-loaders collecting multi-family residential MSW. Six diesel roll-off vehicles

319 collecting commercial waste and cardboard (recyclables) were also observed. As described in

320 Section 2, vehicle instrumentation provided fuel use and collection activity data.

\section{$321 \quad 3.2 .1 \quad$ Fuel Consumption}

Front-loaders and roll-off vehicles used a larger fraction of fuel (Figure 5) while driving

323 than was observed for side-loaders (Figure 2), and also spent more time driving. Front-loaders

324 and roll-offs spent just over half of collection vehicles' operational time driving. Roll-off

325 vehicles used $88 \%$ of fuel while driving, while front-loader diesel and CNG vehicles consumed

$32683 \%$ and $81 \%$, respectively. CNG fuel consumption was tracked in DEL. The observed front-

327 loader vehicles (diesel and CNG) made 15 to 62 stops prior to unloading, and therefore had more

328 stop-and-go driving than diesel roll-off vehicles which made four or fewer stops. The average

329 fuel efficiency for these roll-off vehicles was $2.4 \mathrm{~km} / \mathrm{L}$ (5.7 mpg), while diesel front-loaders

330 were lower at $1.4 \mathrm{~km} / \mathrm{L}(3.3 \mathrm{mpg})$, which is consistent with roll-off vehicles making fewer stops.

331 CNG front-loaders had approximately 35\% lower fuel efficiency than diesel front-loaders,

332 performing at $0.9 \mathrm{~km} / \mathrm{DEL}$ (2.1 miles per DEL). This difference is higher than findings in studies

333 comparing CNG and diesel buses (NREL 1995) which reported 10-30\% lower fuel efficiency for

334 CNG vs. diesel. 


\subsubsection{Multi-family and Commercial Collection: Characterization of Collection Activities}

Figures 6 and 7 show the average collection activity times and distances for front-loader

337 and roll-off vehicles. Minimum and maximum values for each measurement were taken from the

338 average for each truck-day. Front-loaders and roll-off vehicles spend similar time driving to and

339 unloading at the facility (Figure 6). Front-loaders make more stops prior to emptying, and

340 therefore the time at each stop and the distance and time between stops are shorter than for roll-

341 off vehicles. For most observed routes, the garage was co-located with the disposal facility, so

342 "garage to route" and "route to facility" travel segments are approximately equivalent (Figure 7).

343 This is not the case for all collection systems, so it is important to identify these distances for the

344 collection system being analyzed. More details about each measurement are presented in

345 Appendix T-A1.

3464 Single-family Collection: Sample Inputs and Illustrative Results

\section{4.1 Operationally-based Collection Model Default Inputs for Single-Family Collection}

348 The objective of this section is to present a set of default values based on the operational

349 data for single-family collection. This data set can be used to estimate costs and emissions

350 associated with MSW collection using a life-cycle process model in the absence of site-specific

351 data (e.g., Jaunich et al., forthcoming 2016). Table 4 aggregates the values reported in this study

352 and provides a low, middle, and high value for each parameter for use in a collection process

353 model. For analyzing different collection systems, these values should be used selectively to best

354 represent the system of interest. The middle value may be a reasonable starting point, and could

355 be adjusted based on the specifics of the collection area being analyzed.

356 Collection process models typically use the average value of a parameter's distribution as

357 input to represent an average collection system. In this study, some parameters had a large 
358 number of data points, while others did not. In general, for those parameters with few observed

359 data points, the low values represent the lowest observed value, with the middle and high values

360 representing the median and highest of observed data, respectively.

361 Table 4. Input parameter set for single-family residential collection

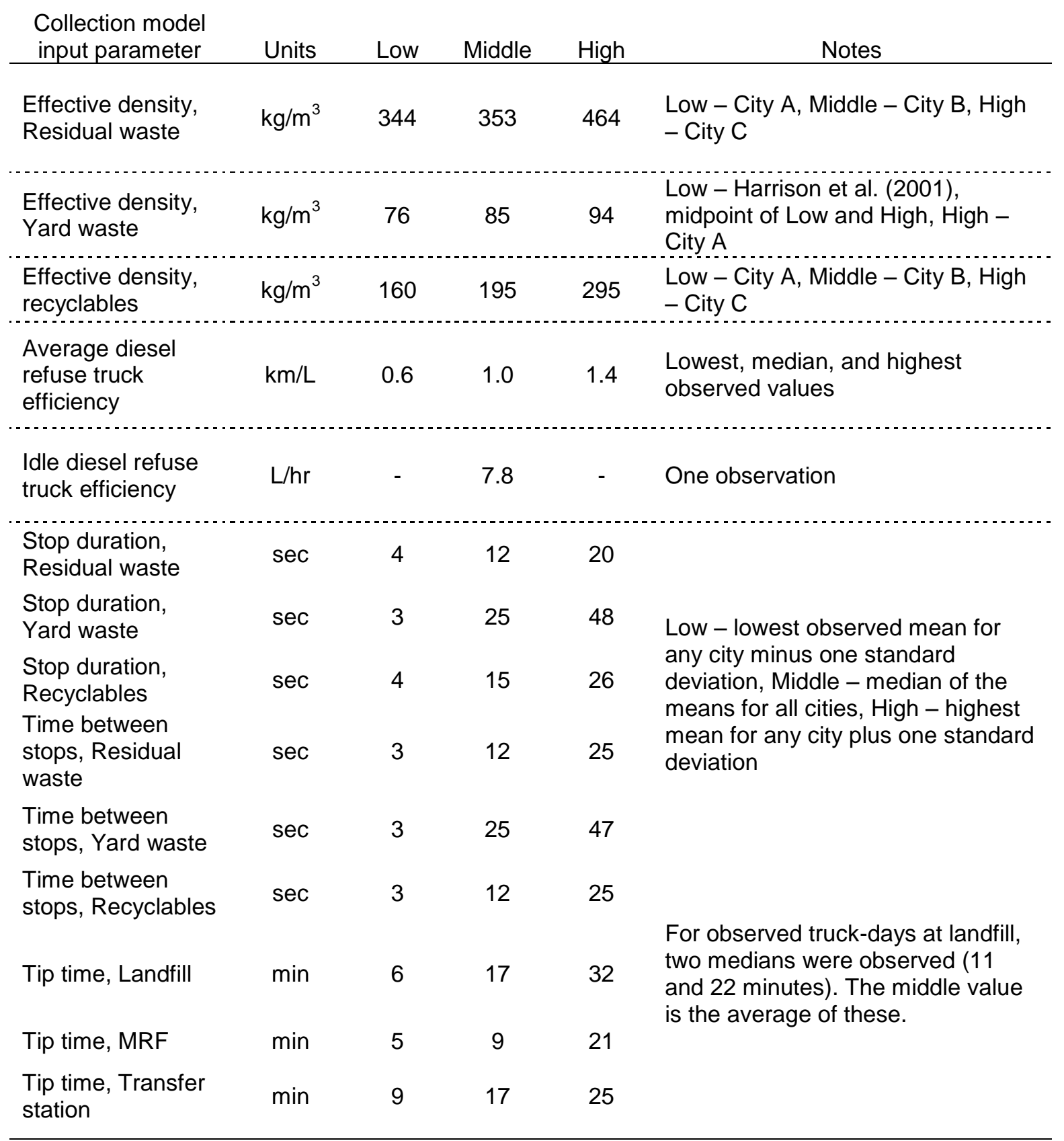




\subsection{Default Inputs: Illustrative Results}

In this section, data from this study were employed in a collection process model

365 (Jaunich et al., forthcoming 2016) to estimate fuel consumption, cost, and emissions associated

366 with different collection systems. The referenced model is a spreadsheet-based representation of

367 MSW collection that includes three sector types (single-family residential, multi-family

368 residential, and commercial) and 10 separate collection services (e.g., residual waste,

369 recyclables, yard waste collection). The model allows the user to change over 50 input

370 parameters based on the details of the analyzed system. This includes inputs such as vehicle type

371 (diesel vs. CNG), labor costs, and collection services offered, as well as fuel efficiency, waste

372 density, and collection activity parameters as discussed in this study. The data in Table 4 were

373 used to create a "better case", "moderate case", and "worse case" and perform illustrative

374 analyses of residential residual waste collection. For some parameters, lower values are more

375 favorable (e.g., lower times and distances means fewer trucks required, less fuel used, and lower

376 cost), while for others, higher values are more favorable (e.g., higher in-truck density results in

377 more waste collected per trip to the landfill).

378 Using the collection process model, fuel consumption, cost, and number of trucks for

379 each of the "better", "moderate", and "worse" case data sets were estimated to illustrate the

380 range of results possible for a representative city. These values are estimated for each collection

381 type (residual waste, yard waste, and recyclables), and then the weighted average is computed to

382 find the cost and fuel use per metric ton of waste for the city. In Jaunich et al. (forthcoming

383 2016), costs, fuel consumption, and number of trucks for City A were compared with model-

384 predicted values for two sample cases. The results for the better, moderate, and worse cases,

385 using the values in Table 4, are compared with empirical and model-predicted results from 
Jaunich et al. (forthcoming 2016) in Table 5 (all model inputs are presented in Appendix Table T-A5). The "moderate case" predicts less than 1\% higher fuel use, and 14\% higher cost, than the

City A model results (Jaunich et al., forthcoming 2016). Compared with the empirical fuel consumption, the moderate case is $22 \%$ higher and the favorable case is $29 \%$ lower.

Table 5. Illustrative results for better-, moderate-, and worse-case inputs

\begin{tabular}{l|ccc}
\hline & $\begin{array}{c}\text { Fuel } \\
(\mathrm{L} / \mathrm{Mg})\end{array}$ & $\begin{array}{c}\text { Number Collection } \\
\text { Vehicles }\end{array}$ & $\begin{array}{c}\text { Cost } \\
(\$ / \mathrm{Mg})^{\mathrm{a}}\end{array}$ \\
\hline Better case $^{\mathrm{b}}$ & 16.6 & 15.9 & 76.8 \\
Moderate case $^{\mathrm{b}}$ & 28.7 & 28.0 & 142.5 \\
Worse case $^{\mathrm{b}}$ & 64.9 & 43.8 & 231.4 \\
City A, Model $^{\mathrm{c}}$ & 28.6 & 25.8 & 124.9 \\
City A, Operational $^{\mathrm{d}}$ & 23.5 & 24.0 & 102.2 \\
\hline
\end{tabular}

${ }^{a}$ Cost includes estimated diesel fuel price of $\$ 0.66 / \mathrm{L}$ (\$2.50/gallon)

${ }^{\mathrm{b}}$ All parameters except those listed in Table 4 take the same values as Jaunich et al. (forthcoming 2016) (see Appendix T-A5)

c Jaunich et al. (2016). Model results are from the referenced paper.

${ }^{\mathrm{d}}$ Jaunich et al. (2016). Operational results are from referenced paper.

This analysis illustrates the importance of model parameterization when modeling a

393 collection area. It also shows the value of using mechanistic models to explore how collection

394 costs and emissions change based on changes in truck performance and type and route

395 efficiency.

\section{Conclusions}

In practice, collection is a non-uniform task that cannot be simplistically characterized

398 due to the many interrelated factors that must be considered. For example, the level of

399 automation of a collection vehicle will influence the time required to collect waste at each stop,

400 as will the skill of the driver or collection workers. While this was not explicitly considered in

401 this study, the data presented here provide insights into valid ranges for several parameters that

402 are critical to the analysis of a collection system. 
This research contributes to the available data related to MSW collection and may be

404 applicable to areas with formal, organized residential or commercial collection in the U.S. and

405 abroad. Field observations of collection vehicle activities as well as data provided by

406 municipalities and disposal facilities were used to determine values for parameters that describe

407 MSW collection. The results illustrate that MSW collection activity parameters can vary

408 substantially with implications for cost, fuel use and truck requirements (Table 5). In the

409 illustrative analysis, fuel consumption was a factor of four higher for the worst-case scenario

410 relative to the best-case scenario, illustrating the importance of site-specific data in estimating

411 collection system performance.

412 Collection vehicles' fuel use was characterized using thousands of hours of recorded

413 collection operations for City D. Comparing this to previous studies, field observations, and

414 other municipality-provided data showed good agreement. Although the collection areas,

415 services offered, and collection vehicles differed, all areas studied had an average fuel economy

416 ranging from 0.6 to $1.4 \mathrm{~km} / \mathrm{L}(1.4$ to $3.3 \mathrm{mpg}$ ) for all single-family collection routes. Front-

417 loaders servicing multi-family and commercial collection averaged $1.4 \mathrm{~km} / \mathrm{L}(3.3 \mathrm{mpg})$, and roll-

418 off vehicles averaged $2.3 \mathrm{~km} / \mathrm{L}$ (5.4 mpg). For single-family collection, times and distances were

419 fairly consistent between a large metropolitan area (City B) and a smaller suburban center (City

420 A), but both cases illustrate that outliers are common. City B's mean stop duration for residual

421 waste was $8 \%$ higher than City A, but $20 \%$ lower for recyclables collection. The mean time

422 between stops for recyclables and residual waste routes ranged from 10.1 to 13.3 seconds for

423 both cities. Because multi-family and commercial collection activities are more difficult to

424 generalize, it is important to measure or estimate the collection distances and times from

425 operational data to develop a representative set of inputs for modeling efforts. 
427 models are necessary for estimating how collection system performance will respond to these 428 changes. Site-specific physical, demographic, and operational aspects of the collection area of

429 interest should be considered where such information is available. The collection data presented 430 here are a starting point for the selection of values for the many required input parameters in a 431 collection process model.

\section{Acknowledgements}

433 This research was supported by the National Science Foundation (CBET-1034059) and 434 the Environmental Research and Educational Foundation. Megan Jaunich was supported by the 435 Lonnie C. Poole/Waste Industries Scholarship through the Environmental Research and

436 Education Foundation. We gratefully acknowledge U.S. municipalities, waste management 437 organizations, and vehicle manufacturers for providing data and facilitating observation of 438 collection activities. Measured refuse truck activity, energy use, and emissions data for City F

439 were provided by H. Christopher Frey and Gurdas Sandhu of North Carolina State University. 440 
Chalkias C., Lasaridi K. Optimizing municipal solid waste collection using GIS. Athens;

444 AG Loannou Theologu 17-23, 15773. World Sci and Eng Acad and Soc; 2009.

Chatzouridis C., Komilis D. A methodology to optimally site and design municipal solid waste transfer stations using binary programming. Resour Conserv Recycl 2012; 60:89-98.

448 Cycle Inventory Parameters Associated with the Collection of Municipal Solid Waste. 2000.

449 Accessed Dec. 122015 from https://mswdst.rti.org/docs/Collection_Model_OCR.pdf and Figures. Accessed Dec 2, 2015. http://www2.epa.gov/sites/production/files/201509/documents/2013_advncng_smm_rpt.pdf activities and estimation of vehicle and labor needs. J Air Waste Manage Assoc 1997; 47:1061-9.

$460 \quad$ Transp Res Rec 2009:38-45. 
466 for life-cycle-based solid waste management. J Comput Civ Eng 2001; 15:44-58.

Ivani Z. Data Collection and Development of New York City Refuse Truck Duty Cycle.

468 SAE Technical Paper Series, SAE International, Powertrain and Fluid Systems Conference and

469 Exhibition, Rosemont, IL October 29-November 12007 2007; 01.

470 Jaunich M. K., Levis J. W., Barlaz M. A., DeCarolis J. F. Municipal Solid Waste

471 Collection Using Life-Cycle Methodology. Journ of Env Eng. Forthcoming, 2016.

472 Jovicic N. M., Boskovic G. B., Vujic G. V., Jovicic G. R., Despotovic M. Z.,

473 Milovanovic D. M. Route Optimization to Increase Energy Efficiency and Reduce Fuel

474 Consumption of Communal Vehicles. Therm Sci 2010; 14:S67-78.

475 Komilis D. P. Conceptual modeling to optimize the haul and transfer of municipal solid 476 waste. Waste Manage 2008; 28:2355-65.

477 Larsen A. W., Vrgoc M., Christensen T. H., Lieberknecht P. Diesel consumption in waste 478 collection and transport and its environmental significance. Waste Manage Res 2009; 27:652-9.

479 Lee D., Zietsman J., Farzaneh M., Johnson J. Characterization of On-Road Emissions of 480 Compressed Natural Gas and Diesel Refuse Trucks. Transp Res Rec 2011:80-9.

481 Levis J. W., Barlaz M. A., DeCarolis J. F., Ranjithan S. R. A generalized multistage

482 optimization modeling framework for life cycle assessment-based integrated solid waste

483 management. Environmental Modelling Software, 2013.

485 diesel, biodiesel and natural gas refuse trucks of the City of Madrid. Appl Energy 2009; 86:6104865. 
488 collection vehicles. Waste Manage 2013; 33:1079-89.

490 Management: Six Case Studies of System Cost and Energy Use. A Summary Report. Nov. 1995

$491 \quad$ NREL/TP-430-20471

North Carolina State University and Research Triangle Institute. Default Data and Data

493 Input Requirements for the Municipal Solid Waste Management Decision Support Tool. 2000.

494 Accessed Dec. 122015 from https://mswdst.rti.org/docs/Inputs_Document_OCR.pdf

495 Rose L., Hussain M., Ahmed S., Malek K., Costanzo R., Kjeang E. A comparative life 496 cycle assessment of diesel and compressed natural gas powered refuse collection vehicles in a 497 Canadian city. Energy Policy 2013; 52:453-61.

499 fuel use, and emissions of front-loader refuse trucks. Atmos Environ 2014; 92:557-65.

$500 \quad$ Sandhu G. S., Frey H. C., Bartelt-Hunt S., Jones E. In-use activity, fuel use, and

501 emissions of heavy-duty diesel roll-off refuse trucks. Jour Air \& Waste Manage. Assoc. 2015;

502 Vol. 65, 3:306-323

504 Emissions of Diesel Side-Loader Refuse Trucks. Atmos Environ 2016; solid waste management. II: Illustrative applications. Jour Env Eng-ASCE 2002a; 128:993-1005.

509 Model development. Jour Env Eng-ASCE 2002b; 128:981-92. 
Sonesson U. Modelling of waste collection - a general approach to calculate fuel

511 consumption and time. Waste Manage Res 2000; 18:115-23.

512 Tavares G., Zsigraiova Z., Semiao V., Carvalho M. G. Optimisation of MSW collection

513 routes for minimum fuel consumption using 3D GIS modelling. Waste Manage 2009; 29:1176-

51485.

515 WIH Resource Group. City of Tucson, AZ: Alternative Fuel Study for Refuse Collection

516 Vehicles - Final Report. 2010. Available

517 http://www.tucsonaz.gov/files/es/City_of_Tucson_Alt_Fuel_Study_-_Final_Report1.pdf.

518 Accessed 3/23/15.

519 Zsigraiova Z., Semiao V., Beijoco F. Operation costs and pollutant emissions reduction

520 by definition of new collection scheduling and optimization of MSW collection routes using

521 GIS. The case study of Barreiro, Portugal. Waste Manage 2013; 33:793-806. 


\section{Appendix}

523 T-A1. Time to unload (tip time) at various disposal facilities from check-in through check524 out

Tip time (minutes)

Location and facility information

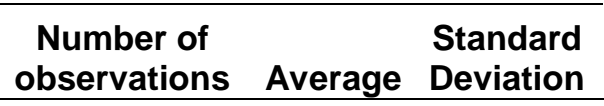

\begin{tabular}{|c|c|c|c|c|c|}
\hline \multirow{3}{*}{$\stackrel{\frac{1}{2}}{\frac{\pi}{0}}$} & $\begin{array}{c}\text { Residual Waste, } \\
\text { Diesel }\end{array}$ & City E landfill & 2 & 12 & - \\
\hline & $\begin{array}{l}\text { Recycling, } \\
\text { Diesel }\end{array}$ & Private Recycling Facility & 2 & 15 & - \\
\hline & $\begin{array}{l}\text { Yard Waste, } \\
\text { Diesel }\end{array}$ & City E landfill & 1 & 14 & - \\
\hline \multirow{3}{*}{$\stackrel{m}{\frac{m}{0}}$} & $\begin{array}{c}\text { Residual Waste, } \\
\text { Diesel }\end{array}$ & Private Landfill & 16 & 22 & 10 \\
\hline & $\begin{array}{l}\text { Residual Waste, } \\
\text { CNG }\end{array}$ & Private Transfer Station & 22 & 12 & 7 \\
\hline & $\begin{array}{l}\text { Recycling, } \\
\text { Diesel }\end{array}$ & Material Recovery Facility & 26 & 14 & 7 \\
\hline \multirow{4}{*}{$\stackrel{w}{\frac{W}{U}}$} & $\begin{array}{c}\text { One day of disposals } \\
\text { observed }\end{array}$ & Material Recovery Facility & 23 & 7 & 2 \\
\hline & $\begin{array}{l}\text { Residential } \\
\text { Loads }\end{array}$ & City E Transfer Station & 153 & 17 & 8 \\
\hline & $\begin{array}{l}\text { Residential } \\
\text { Loads }\end{array}$ & City E Landfill & 410 & 11 & 5 \\
\hline & City E disposals & Material Recovery Facility & 657 & 9 & 4 \\
\hline
\end{tabular}


528 T-A2. Collection - Time at Stop and Time between Stops

\begin{tabular}{|c|c|c|c|c|c|c|c|c|c|c|c|c|c|}
\hline & \multirow[b]{2}{*}{$\begin{array}{c}\# \\
\text { Routes }\end{array}$} & \multicolumn{3}{|c|}{ Stop Duration (sec) } & \multirow[b]{2}{*}{ Q1 } & \multirow[b]{2}{*}{ Med } & \multirow[b]{2}{*}{ Q3 } & \multicolumn{3}{|c|}{ Transit Times (sec) } & \multirow[b]{2}{*}{ Q1 } & \multirow[b]{2}{*}{ Med } & \multirow[b]{2}{*}{ Q3 } \\
\hline & & Mean & Mode & $\mathrm{SD}$ & & & & Mean & Mode & SD & & & \\
\hline City A RW & 2 & 11.4 & 7.7 & 7.2 & 7.5 & 9.8 & 12.0 & 12.5 & 7.4 & 13.6 & 5.5 & 9.3 & 13.1 \\
\hline City A Rec ${ }^{b}$ & 1 & 16.9 & 11.3 & 15.2 & 10.5 & 12.8 & 15.2 & 13.1 & 7.6 & 12.4 & 5.3 & 9.4 & 13.5 \\
\hline City A YW & 1 & 25.2 & 15.1 & 22.9 & 4.9 & 16.6 & 28.2 & 24.7 & 15.1 & 22.2 & 4.3 & 15.8 & 27.3 \\
\hline City B RW & 16 & 12.3 & 9.0 & 10.8 & 8.0 & 10.0 & 12.0 & 11.2 & 6.0 & 12.6 & 5.0 & 8.0 & 11.0 \\
\hline City B Rec & 17 & 13.0 & 4.0 & 16.0 & 5.5 & 9.0 & 12.5 & 10.3 & 3.0 & 13.2 & 4.0 & 8.0 & 12.0 \\
\hline
\end{tabular}

529

530 T-A3. Average Fuel Economy while Driving $(\mathrm{km} / \mathrm{L})$ (Figure 1)

\begin{tabular}{|c|c|c|c|c|c|c|c|c|c|c|c|}
\hline & $\begin{array}{c}\mathrm{A}, \\
\mathrm{RW}^{\mathrm{a}}\end{array}$ & $\begin{array}{c}A, \\
\operatorname{Rec}^{b}\end{array}$ & $\begin{array}{l}\text { B, } \\
\text { RW }\end{array}$ & $\begin{array}{l}\text { B, } \\
\text { Rec }\end{array}$ & $\begin{array}{c}\mathrm{C}, \\
\mathrm{RW}\end{array}$ & $\begin{array}{c}\text { C, } \\
\text { Rec }\end{array}$ & $\begin{array}{l}\text { D, } \\
\text { RW }\end{array}$ & $\begin{array}{c}\text { F, } \\
\text { RW }\end{array}$ & $\begin{array}{c}F \\
\text { RW }^{\wedge}\end{array}$ & $\begin{array}{l}\text { Agar, } \\
2007\end{array}$ & $\begin{array}{l}\text { Farz., } \\
2009\end{array}$ \\
\hline Average fuel economy, km/L & 0.7 & 1.0 & 0.9 & 0.8 & 1.0 & 1.0 & 1.1 & 1.3 & 0.6 & 0.9 & 1.6 \\
\hline
\end{tabular}

532 T-A4. Effective in-truck density for City $\mathrm{C}$ residual waste and recyclables $\left(\mathrm{kg} / \mathrm{m}^{3}\right)$

\begin{tabular}{lcccccccc} 
& $\begin{array}{c}\text { Truck- } \\
\text { days }\end{array}$ & Mean & SD & Q1 & Med & Q3 & Max & Min \\
\hline City C, RW & 880 & 344.5 & 114.3 & 301.6 & 376.6 & 417.6 & 780.5 & 2.0 \\
City C, Rec & 641 & 275.1 & 79.3 & 234.6 & 273.8 & 320.0 & 652.3 & 8.8 \\
\hline
\end{tabular}




\begin{tabular}{|c|c|c|c|c|c|}
\hline Parameter description & Units & Name & Res & Rec & YW \\
\hline \multicolumn{6}{|l|}{ Collection schedule } \\
\hline $\begin{array}{l}\text { Number of households at one } \\
\text { stop }\end{array}$ & households/stop & HS & 1 & 1 & 1 \\
\hline Participation rate & fraction of stops & Prtcp & $1^{a}$ & $0.75^{\mathrm{a}}$ & $0.5^{\mathrm{a}}$ \\
\hline Collection frequency & $1 /$ week & $\mathrm{Fr}$ & 1 & 1 & 1 \\
\hline Number of working days a week & days/week & $C D$ & 4 & 4 & 4 \\
\hline Actual working hours a day & hours/vehicle-day & WV & 9 & 9 & 9 \\
\hline Working hours a day for wage & hours/person-day & WP & 9 & 9 & 9 \\
\hline \multicolumn{6}{|l|}{ Collection Rules } \\
\hline $\begin{array}{l}\text { Is the route or truck subject to a } \\
\text { weight limit? } \\
\text { If subject to a weight limit, max } \\
\text { collected weight before unload }\end{array}$ & Mg/vehicle & $\begin{array}{l}\text { Yes or No } \\
\text { max_weight }\end{array}$ & No & No & No \\
\hline \multicolumn{6}{|l|}{ Collection operation times } \\
\hline $\begin{array}{l}\text { Loading time at one service stop } \\
\text { Travel time between service stops } \\
\text { (based on } 100 \% \text { Participation) }\end{array}$ & $\begin{array}{l}\min / \text { stop } \\
\min / \text { stop }\end{array}$ & Tbtw & & Table 4 & \\
\hline $\begin{array}{l}\text { Travel time between route and } \\
\text { disposal facility } \\
\text { Time to unload at disposal facility } \\
\text { (tip time) }\end{array}$ & $\begin{array}{l}\mathrm{min} / \text { trip } \\
\mathrm{min} / \text { trip }\end{array}$ & $\begin{array}{l}\text { Trf } \\
\text { S }\end{array}$ & & & \\
\hline Lunch time & $\min /$ day-vehicle & $\mathrm{F} 1$ & $30^{a}$ & $30^{a}$ & $30^{a}$ \\
\hline Is truck left idling during lunch? & Yes or No & F1_idle & Yes & Yes & Yes \\
\hline Break time & $\min /$ day-vehicle & $\mathrm{F} 2$ & $30^{a}$ & $30^{a}$ & $30^{a}$ \\
\hline $\begin{array}{l}\text { Is truck left idling during break? } \\
\text { Time from garage to collection } \\
\text { route } \\
\text { Time from disposal facility to } \\
\text { garage }\end{array}$ & $\begin{array}{l}\text { Yes or No } \\
\text { min/day-vehicle } \\
\text { min/day-vehicle }\end{array}$ & $\begin{array}{l}\text { F2_idle } \\
\text { Tgr } \\
\text { Tfg }\end{array}$ & Yes & Table 4 & Yes \\
\hline \multicolumn{6}{|l|}{ Labor } \\
\hline $\begin{array}{l}\text { Does a driver work as a collector? } \\
\text { Number of additional collectors } \\
\text { per vehicle } \\
\text { Worker backup rate }\end{array}$ & $\begin{array}{l}\text { Yes or No } \\
\text { persons/vehicle } \\
\text { backup workers/ } \\
\text { collection workers }\end{array}$ & $\begin{array}{l}\mathrm{Nw} \\
\mathrm{bw}\end{array}$ & $\begin{array}{c}\text { Yes } \\
0 \\
0.1^{a}\end{array}$ & $\begin{array}{c}\text { Yes } \\
0 \\
0.1^{a}\end{array}$ & $\begin{array}{c}\text { Yes } \\
0 \\
0.1^{a}\end{array}$ \\
\hline \multicolumn{6}{|l|}{ Economic data } \\
\hline Fringe benefit rate & $\begin{array}{l}\text { fringe benefit } \\
\text { pay/wage pay }\end{array}$ & a & $0.46^{a}$ & $0.46^{a}$ & $0.46^{\mathrm{a}}$ \\
\hline Other expenses rate & \$/worker-year & $d$ & $12114^{a}$ & $12114^{a}$ & $12114^{a}$ \\
\hline Administrative rate & $\begin{array}{l}\text { administratıve cost/ } \\
\text { (capital+operating cost) }\end{array}$ & e & $0.12^{a}$ & $0.12^{a}$ & $0.12^{\mathrm{a}}$ \\
\hline Hourly wage for a collector & \$/hour-person & Wa & $12.96^{\mathrm{a}}$ & $12.96^{\mathrm{a}}$ & $12.96^{\mathrm{a}}$ \\
\hline Hourly wage for a driver & \$/hour-person & Wd & $15^{\mathrm{a}}$ & $15^{a}$ & $15^{\mathrm{a}}$ \\
\hline
\end{tabular}




\begin{tabular}{|c|c|c|c|c|c|}
\hline Parameter description & Units & Name & Res & Rec & YW \\
\hline \multicolumn{6}{|l|}{ Vehicle operational parameters } \\
\hline Backup rate for vehicles & $\begin{array}{l}\text { backup vehicle/ } \\
\text { collection vehicle }\end{array}$ & bv & $0.1^{\mathrm{a}}$ & $0.1^{\mathrm{a}}$ & $0.1^{\mathrm{a}}$ \\
\hline Utilization factor & $\begin{array}{l}\text { max occupied yd } d^{3} / \\
\text { usable } y d^{3}\end{array}$ & Ut & $0.8^{\mathrm{a}}$ & $0.8^{\mathrm{a}}$ & $0.8^{a}$ \\
\hline Usable vehicle capacity & $\mathrm{m}^{3}$ & $\mathrm{v}$ & $31^{a}$ & $31^{a}$ & $31^{a}$ \\
\hline Economic life of a vehicle & year & Lt & $7^{a}$ & $7^{a}$ & $7^{a}$ \\
\hline Vehicle type & & & ASL & ASL & ASL \\
\hline \multirow{3}{*}{$\begin{array}{l}\text { Unit price of a vehicle } \\
\text { Vehicle operation and } \\
\text { maintenance cost } \\
\text { Assumed compartment } \\
\text { compaction density }\end{array}$} & $\$ /$ vehicle & $\mathrm{Pt}$ & $240000^{c}$ & $240000^{c}$ & $240000^{c}$ \\
\hline & $\$ /$ vehicle & c & $40000^{c}$ & $40000^{c}$ & $30000^{c}$ \\
\hline & $\mathrm{kg} / \mathrm{m}^{3}$ & $d$ & \multicolumn{3}{|c|}{ Table 4} \\
\hline \multicolumn{6}{|l|}{ Travel speeds } \\
\hline Between collection stops & $\mathrm{km} / \mathrm{hour}$ & Vbet & \multirow{2}{*}{\multicolumn{3}{|c|}{$\begin{array}{l}\text { Calculated based on times in } \\
\text { Table } 4^{d} \text { and distances, below }\end{array}$}} \\
\hline $\begin{array}{l}\text { From collection route to facility } \\
\text { From garage to route in the } \\
\text { morning }\end{array}$ & $\begin{array}{l}\mathrm{km} / \text { hour } \\
\mathrm{km} / \text { hour }\end{array}$ & $\begin{array}{l}\text { Vrf } \\
\text { Vgr }\end{array}$ & & & \\
\hline From facility to garage & $\mathrm{km} / \mathrm{hour}$ & $\mathrm{Vfg}$ & & & \\
\hline \multicolumn{6}{|l|}{ Distances } \\
\hline $\begin{array}{l}\text { Distance between collection route } \\
\text { and destination }\end{array}$ & $\mathrm{km}$ & Drf & $20.0^{b}$ & $34.6^{b}$ & $28.0^{\mathrm{b}}$ \\
\hline $\begin{array}{l}\text { Fraction of route to destination } \\
\text { which is highway } \\
\text { Distance between destination and }\end{array}$ & $\mathrm{km}$ & fDrf & 0.5 & 0.5 & 0.5 \\
\hline garage & $\mathrm{km}$ & Dfg & $28.0^{\mathrm{b}}$ & $40.2^{b}$ & $36.1^{\mathrm{b}}$ \\
\hline $\begin{array}{l}\text { Fraction of destination to garage } \\
\text { which is highway }\end{array}$ & $\mathrm{km}$ & fDfg & 0.5 & 0.5 & 0.5 \\
\hline $\begin{array}{l}\text { Distance between service stops } \\
\text { (regardless of non-participation) }\end{array}$ & $\mathrm{km}$ & D100 & $0.05^{b}$ & $0.05^{b}$ & $0.05^{b}$ \\
\hline $\begin{array}{l}\text { Distance between garage and } \\
\text { collection route } \\
\text { Fraction of distance between }\end{array}$ & $\mathrm{km}$ & Dgr & $5.95^{b}$ & $3.54^{b}$ & $6.44^{\mathrm{b}}$ \\
\hline is highway & $\mathrm{km}$ & fDgr & 0 & 0 & 0 \\
\hline
\end{tabular}




\begin{tabular}{|c|c|c|c|c|c|}
\hline Parameter description & Units & Name & Res & Rec & YW \\
\hline \multicolumn{6}{|l|}{ Fuel usage rates } \\
\hline $\begin{array}{l}\text { Fuel split: fraction of stops } \\
\text { serviced by CNG vehicles }\end{array}$ & $\%$ & Fract_CNG & 0 & 0 & 0 \\
\hline $\begin{array}{l}\text { Fuel split: fraction of stops } \\
\text { serviced by diesel vehicles }\end{array}$ & $\%$ & Fract_Dies & 1 & 1 & 1 \\
\hline CNG average fuel usage & km/diesel equiv. $L$ & $e_{\mathrm{avg}} \overline{C N G}^{\mathrm{e}, \mathrm{f}}$ & - & - & - \\
\hline CNG during urban driving & $\mathrm{km} /$ diesel equiv. $\mathrm{L}$ & $\mathrm{ef}_{u \_} \mathrm{CNG}$ & - & - & - \\
\hline CNG during highway driving & km/diesel equiv. $\mathrm{L}$ & $\mathrm{ef}_{h \_C N G}$ & - & - & - \\
\hline $\begin{array}{l}\text { CNG during collection } \\
\text { CNG while idling /dropping off } \\
\text { waste }\end{array}$ & $\begin{array}{l}\mathrm{km} / \text { diesel equiv. } \mathrm{L} \\
\text { diesel equivalent } \mathrm{L} / \mathrm{hr}\end{array}$ & $\begin{array}{l}\mathrm{ef}_{\mathrm{b}_{2}} \mathrm{CNG} \\
\mathrm{ef}_{\mathrm{i} \_} \mathrm{CNG}\end{array}$ & - & - & - \\
\hline Diesel average fuel usage & $\mathrm{km} / \mathrm{L}$ & $\mathrm{ef}_{\mathrm{avg}} \mathrm{e}$ & \multicolumn{3}{|c|}{ Table 4} \\
\hline Diesel during urban driving & $\mathrm{km} / \mathrm{L}$ & $\mathrm{ef}_{\mathrm{u}}$ & - & - & - \\
\hline Diesel during highway driving & $\mathrm{km} / \mathrm{L}$ & $\mathrm{ef}_{\mathrm{h}}{ }^{\dagger}$ & - & - & - \\
\hline $\begin{array}{l}\text { Diesel during collection } \\
\text { Diesel while idling/dropping off } \\
\text { waste }\end{array}$ & L/hour & $\begin{array}{l}\mathrm{ef}_{\mathrm{c}} \\
\mathrm{Efi}\end{array}$ & - & - & - \\
\hline \multicolumn{6}{|l|}{ Garage and office parameters } \\
\hline $\begin{array}{l}\text { Maintenance area per collection } \\
\text { vehicle }\end{array}$ & $\mathrm{m}^{2} /$ vehicle & grg_area & $37.2^{\mathrm{a}}$ & $37.2^{a}$ & $37.2^{a}$ \\
\hline Office area per collection vehicle & $\mathrm{m}^{2} /$ vehicle & off_area & $1.86^{\mathrm{a}}$ & $1.86^{\mathrm{a}}$ & $1.86^{\mathrm{a}}$ \\
\hline $\begin{array}{l}\text { Maintenance area electricity } \\
\text { consumption rate } \\
\text { Office area electricity } \\
\text { consumption rate }\end{array}$ & $\begin{array}{l}\mathrm{kWh} / \text { day }-\mathrm{m}^{2} \\
\mathrm{kWh} / \text { day- } \mathrm{m}^{2}\end{array}$ & grg_enrg & $\begin{array}{l}0.00001^{a} \\
0.00002^{a}\end{array}$ & $\begin{array}{l}0.00001^{a} \\
0.00002^{a}\end{array}$ & $\begin{array}{l}0.00001^{a} \\
0.00002^{a}\end{array}$ \\
\hline \multicolumn{6}{|l|}{$\begin{array}{l}\text { Mixed waste and recyclables } \\
\text { storage }\end{array}$} \\
\hline Unit price of a bin & $\$ /$ bin & $\mathrm{Pb}$ & $7.59^{a}$ & $7.59^{a}$ & $7.59^{a}$ \\
\hline Number of bins for each house & bins/house & $\mathrm{Rb}$ & $1^{\mathrm{a}}$ & $1^{\mathrm{a}}$ & $1^{a}$ \\
\hline \multicolumn{6}{|c|}{$\begin{array}{l}\text { a Values adapted from Curtis and Dumas (2007), Harrison et al. (2001), Solano et al. (2002a and 2002b), } \\
\text { Curtis and Dumas (2000), NCSU and RTI (2000) }\end{array}$} \\
\hline \multicolumn{6}{|c|}{$\begin{array}{l}{ }^{b} \text { Data from observation of City A collection routes } \\
\text { c } \text { Truck and operations and maintenance costs from personal communications with waste collectors and truck } \\
\text { manufacturer (2013-2014). } \\
\text { d Speed calculated based on distance and time for each segment (distances are representative of those used } \\
\text { for City A (Jaunich et al. 2016), and times based on ranges of operational data reported in Table 4). }\end{array}$} \\
\hline
\end{tabular}




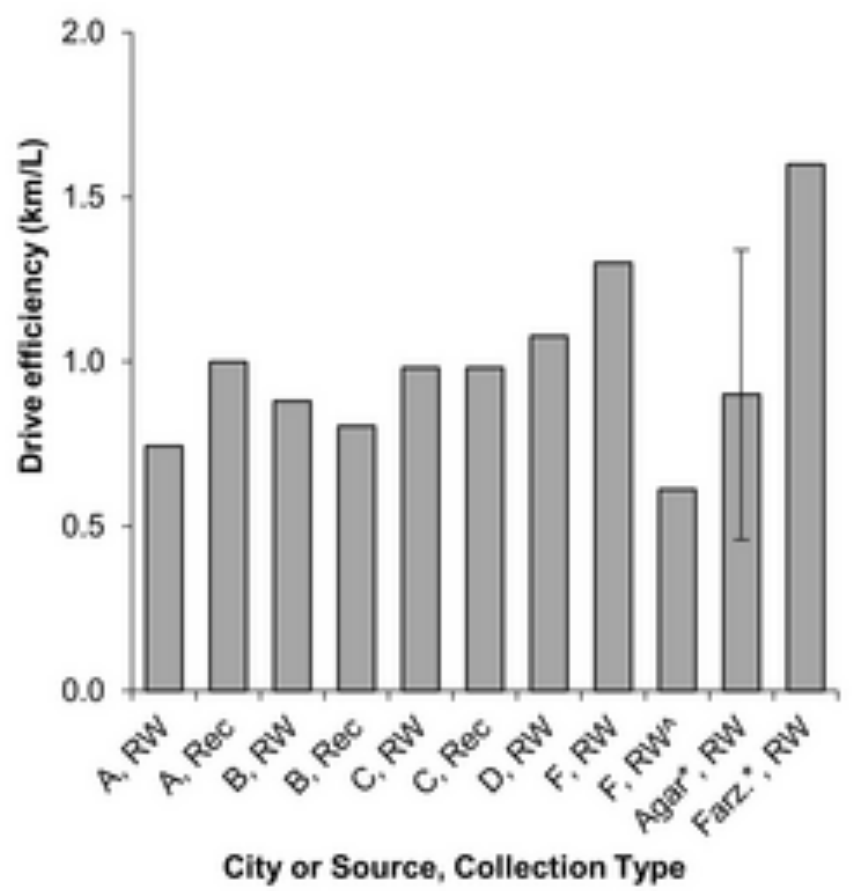

City or Source, Collection Type 


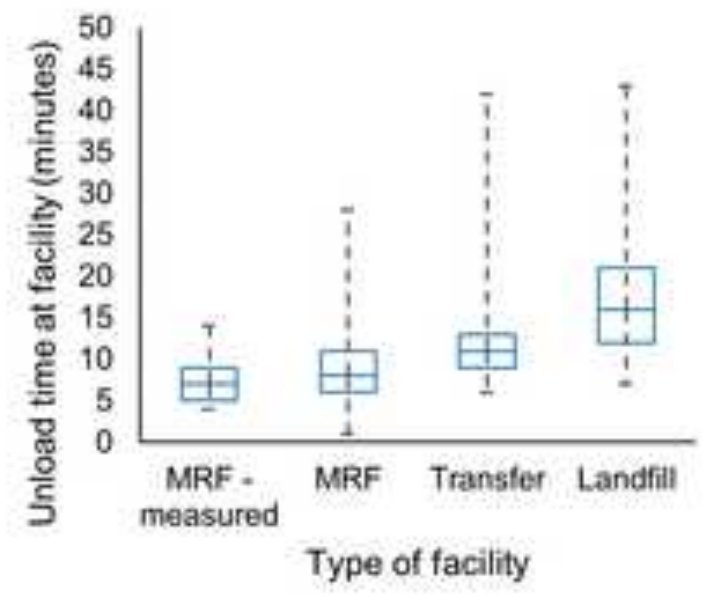

$$
\text { Type of facility }
$$




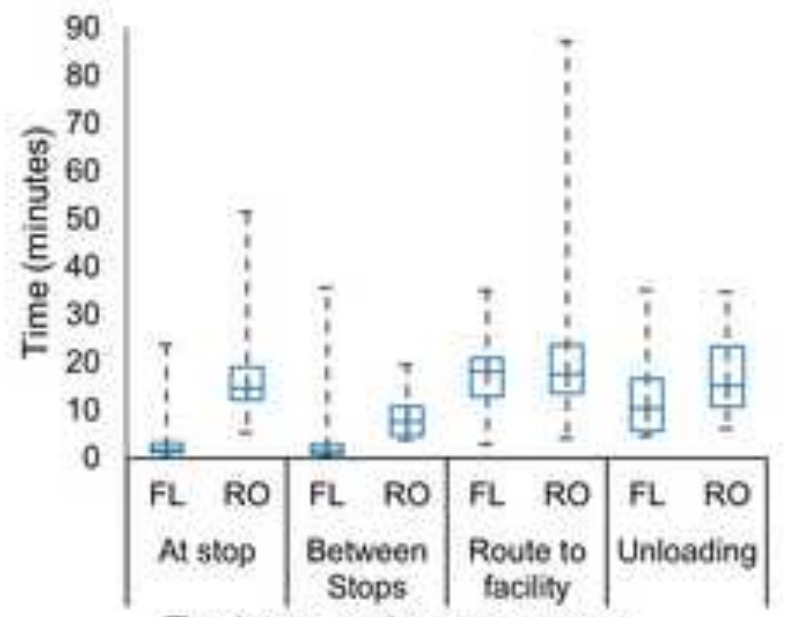

Truck type and route segment 


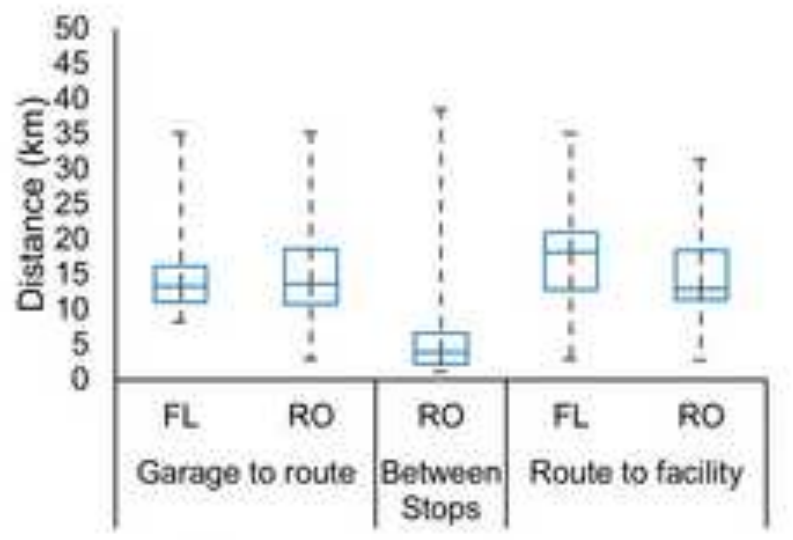

Truck type and route segment 
Figures for Jaunich et al. "Characterization of Municipal Solid Waste Collection Operations"

Figure 1. Single or 1.5 column width

Figure 2. Single column width

Figure 3. Single column width

Figure 4. Single column width

Figure 5. Single column width

Figure 6. Single or 1.5 column width

Figure 7. Single or 1.5 column width 
Figure 1. Overall Average Fuel Economy while Driving $(\mathbf{k m} / \mathbf{L})$

City designated by A through F (Table 1); Collection Type: RW - Residual waste, Rec Recyclables, YW - Yard waste. City F, RW^ represents CNG routes, efficiency presented as km per diesel equivalent liter $(\mathrm{km} / \mathrm{DEL})$ [1 DEL contains the energy equivalent of one liter of diesel fuel (approximately 35.8 GJ/L)]. Data in Appendix Table A-T3.

* Agar et al. 2007, Farzaneh et al. 2009

Figure 2. Portion of total fuel and time used while driving and idling for automated side loader (ASL) vehicles by city (D and F) and fuel type (Diesel and CNG)

Figure 3. Stop duration and transit time between stops. The center line is the median, and the bottom and top of the boxes are the $25^{\text {th }}$ and $75^{\text {th }}$ percentiles, respectively (the inter quartile range, or IQR). The top bar is the $75^{\text {th }}$ percentile plus $1.5 \cdot \mathrm{IQR}$, and the bottom bar is the $25^{\text {th }}$ percentile minus $1.5 \cdot \mathrm{IQR}$. (The dashed lines and bars encompass approximately $95 \%$ of the data.)

Figure 4. Frequency of tip times observed for City E, including one day of tips measured at single-stream MRF (MRF - measured), and facility-reported tip times for a single-stream MRF (MRF), transfer station (Transfer), and a landfill (Landfill). The center line is the median, and the bottom and top of the boxes are the $25^{\text {th }}$ and $75^{\text {th }}$ percentiles, respectively. The top bar is the $75^{\text {th }}$ percentile plus $1.5 \cdot \mathrm{IQR}$, and the bottom bar is the $25^{\text {th }}$ percentile minus 1.5·IQR.

Figure 5. Portion of total fuel and time used while driving and idling for roll-off (RO) and front-loader (FL) for City $F$

Figure 6. Average collection times for front-loader (FL) and roll-off (RO) vehicles. FLs make more frequent, shorter stops but have comparable tip times.

Figure 7. Average collection distances for front-loader (FL) roll-off (RO) vehicles. 